\title{
The Feasibility of Organic Methods of Weed Control in Organic Peanut Crop
}

\author{
Rowe, Sedrick, Sharif-Harris, Hamidah, Riley, Clarence, Samples, Oreta \\ Dept. of Veterinary Science and Public Health \\ 1005 State University Drive \\ PO Box 4370 \\ Fort Valley, Ga 31030 \\ United States
}

\section{Introduction}

The organic fruit and vegetable industry is growing each year with a total of 136 organic certified farmers listed in the state of Georgia in 2018 according to Georgia Organics. Georgia Organics is a member-supported, non-profit organization connecting organic food from Georgia farms to Georgia consumers and was initially established in the 1970s. Growing organic peanuts is economically feasible to farmers and also a healthier alternative to conventional peanuts. In the US, more than $99 \%$ of peanut farms use conventional farming practices including the use of fungicide and pesticides, leaving only $1 \%$ of the peanuts grown to be regarded as "organic". The USDA found different pesticides in peanut butter with the chemical piperonyl butoxide, a carcinogen, found 26.9 percent of the time in a recent study (Hauser 1982). Organic peanuts offer a healthier alternative for those concerned with the possibility of residual toxins in consumable peanut products.

The purpose of this Thesis is to research current weed control practices, the feasibility of not using chemicals in control of weeds, and the resulting germination percentage of organic peanuts which have received no chemical treatments (i.e. fungicides, pesticides, herbicides) and are truly organic. The overall research effort began as a weed control strategy based on intensive cultivation that includes using the right equipment in conjunction with cultural practices that enhance peanut competition with weeds for nutrients without the use of herbicides. Research has shown that peanuts can help control blood sugar in both healthy individuals and those with type 2 diabetes (Kirk, Meyer, 2000 and Jenkins, 2011) and therefore have implications as public health preventative strategies. The discovery that highly refined organic peanut oil may not trigger allergic reactions is also a serious implication for the consumer who favors peanut oil for cooking. The question that drives this Thesis project is: will growing organic peanuts produce a sufficient yield to be provided to consumers seeking the health benefits of peanuts raised without the use of synthetic pesticides, herbicides, and fungicides?

\section{Statement of Problem}

The problem that drives this Thesis research project involves trying to get untreated peanut seeds to sprout; something that has been a huge challenge to farmers trying to grow organic peanuts. This may in fact be due to competition for nutrition among young sprouts, weeds and other indigenous plants. Many organic growers in the southern parts of the state of Georgia have adopted the practice of using different methods to substitute synthetic amendments to the soil and crop to add proper nutrients and also protect from diseases or insect. The farm that will support this Thesis research through growth of organic peanuts is not currently using any type of organic or systemic fungicide, pesticide, or herbicide; the land has been certified organic by Georgia Crop Improvement Association (GCIA). The research will involve growing organic peanuts to measure the yield, germination percent and subsequent weed control without use of herbicides to be sold commercially to consumers seeking organic peanuts and peanut products as a healthy alternative.

\section{Research Design}

The project involves a mixed methods approach to the research as it involves field experimentation and will examine not only the quality of the plants but the quantity of the yield of several one acre plots, each sown with a different variety for a minimum of 2,000 pounds per acre without the use of growth promoting chemicals to include herbicides, pesticides and insecticides. Three different peanut varieties will be utilized in the study; GA-06G, GA-12Y, and Florrun 331. 


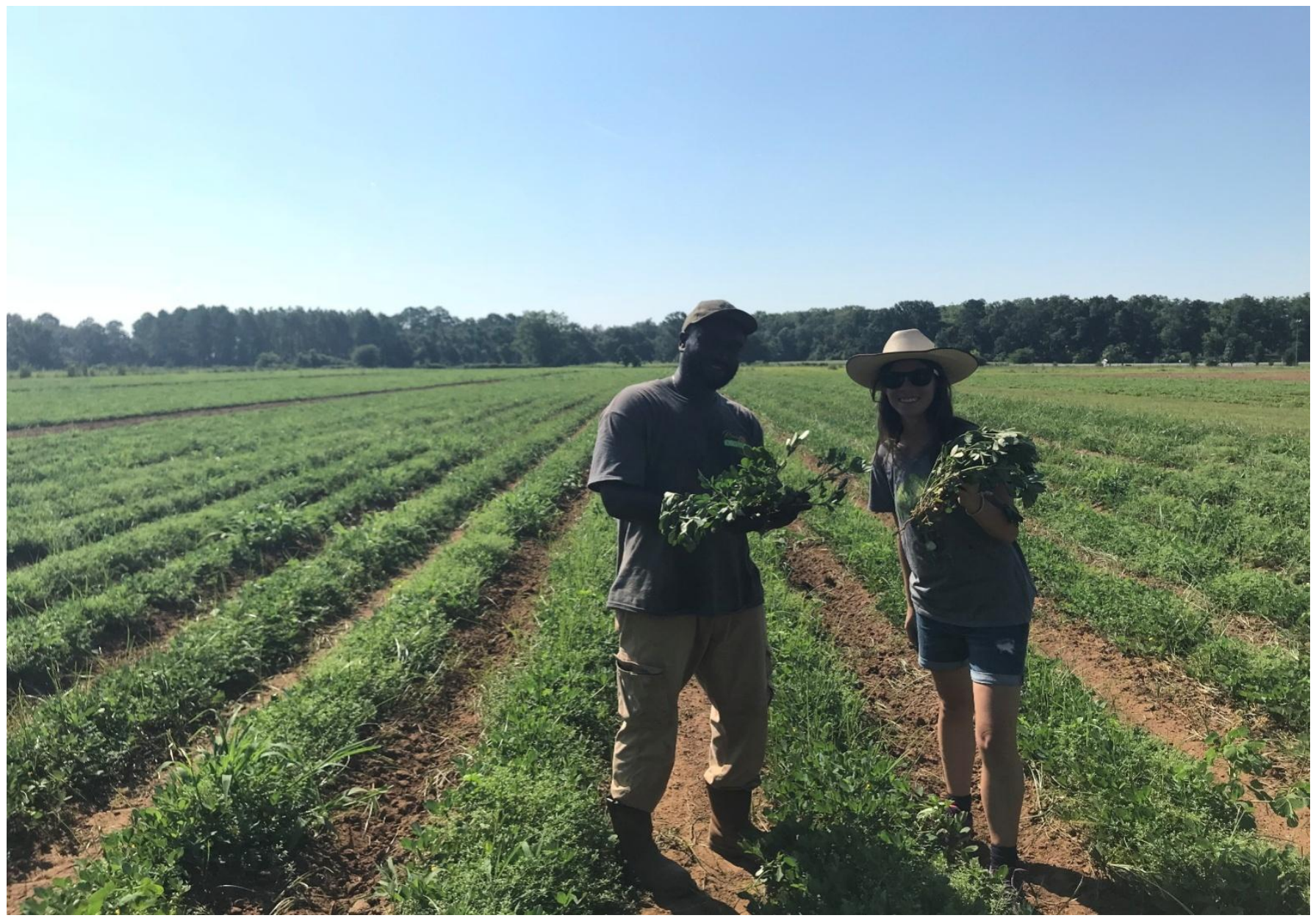

\section{Hypothesis/Null Hypothesis}

H1: GA-o6G peanut variety will not germinate and produce a minimum of 2,440 pounds per acre without the use of growth promoting chemicals to include: herbicides, pesticides and insecticides.

H0: Ga-06G peanut variety will germinate and produce a minimum of 2,440 pounds per acre without the use of growth promoting chemicals to include herbicides, pesticides and insecticides.

H2: GA-12Y peanut variety will germinate and produce a minimum of 2,499 pounds per acre without the use of growth promoting chemicals to include herbicides, pesticides and insecticides.

H0: GA-12Y peanut variety will not germinate and produce a minimum of 2,499 pounds per acre without the use of growth promoting chemicals to include: herbicides, pesticides and insecticides.

H3: Florrun 331 peanut variety will germinate and produce a minimum of 2,042 pounds per acre without the use of growth permuting chemicals to include: herbicides, pesticides and insecticides.

Ho: Florrun 331 peanut variety will not germinate and produce a minimum of 2,042 pounds per acre without the use of growth permuting chemicals to include: herbicides, pesticides and insecticides.

\section{Delimitations}

- Peanuts required soil temperature for germination.

- Sowing of peanut seeds 1 to $11 / 2$ inches deep and 6 to 8 inches apart. Row spacing for bunch types should be 24 inches and 36 inches for runner types

- The flowering and fruiting of peanuts

- Harvesting the peanuts

\section{Limitations}

- The weather can make it hard to plant and cultivate the plant before and during planting process.

- Bad seeds can make there be a low germination percentage. 
- Too much rain will make to make weeds grow and hard to manage.

- Weeds grow out of control can stun growth of the peanuts

- Not storing peanuts at right temperature and result in mold in peanuts

\section{Assumptions}

The following assumptions may be made regarding this project:

There will be a normal growing season in South Georgia during the research time

The three varieties of peanut seeds will be readily available

The three varieties will grow in South Georgia

\section{Definitions}

Conventional: refers to farming systems which include the use of synthetic chemical fertilizers, pesticides, herbicides and other continual inputs

Fungicide: a chemical that destroys fungus.

Germinate: To develop into a plant as from a seed, spore or bulb.

Herbicide: a substance that is toxic to plants and is used to destroy unwanted vegetation.

Insecticides: a substance used for killing insects.

Irrigation: the supply of water to land or crops to help growth, typically by means of channels

Organic: relating to or derived by living matter.

Peanut: the oval seed of a South American plant, widely roasted and salted and eaten as a snack.

Pesticides: a substance used for destroying insects or other organisms harmful to cultivated plants or to animals.

Production Yield: also known as "first time yield", this is a number of good units produced divided by the number of total units going into the process.

Synthetic: made by chemical synthesis, especially to imitate a natural product.

\section{Literature Review}

The literature review is conducted using word/phrases to include: runner type varieties of peanut, which is a highyielding, TSWV-resistant and white mold resistant, medium seeded, runner-type variety released by the Georgia Agricultural Experiment Stations and developed at the University of Georgia, Coastal Plain Experiment Station, and Tifton Campus. Georgia-06G: A high-yielding, large-seeded, runner-type variety, Georgia-06G was developed at the UGA Coastal Plain Experiment Station, Tifton. The variety has shown a high level of resistance to TSWV. Georgia06G has an intermediate or decumbent runner growth habit, dark green foliage and medium maturity similar to Georgia Green. (Albert K. Culbreath and Xuelin Luo. (2018)

European explorers first discovered peanuts in Brazil.Records show that it wasn't until the early 1800s that peanuts were grown as a commercial crop in the United States. They were first grown in Virginia and used mainly for oil, food and as a cocoa substitute. At that time, peanuts were regarded as a food for livestock and the poor and were considered difficult to grow and harvest. Peanuts are currently the 12th most valuable cash crop grown in the United States with a farm value of over one billion U.S. dollars, according to The American Peanut Council. Unlike other countries, the prime market for U.S. peanuts is in edible consumption and the marketing and production focus continue to focus in that direction. (Hammons, R.O. 1973)

In 2014, Georgia (over 46 percent) grew the largest proportion of all peanuts followed by Florida (nearly 13 percent), Alabama (nearly 11 percent), Texas (nearly nine percent), South Carolina (about eight percent) and North Carolina (about seven percent). Together, Mississippi, Virginia, Oklahoma, Arkansas, New Mexico, Louisiana and Missouri each produced six percent of the U.S. peanut crop. When the plant has matured and the peanuts are ready for harvest, the farmer waits until the soil is not too wet or too dry before digging in order to avoid damage to the nut. When conditions are right, a digger is driven up and down the green rows of peanut plants. The digger pulls up the plant, gently shakes off any lingering soil, rotates the plant and lays it back down in a "windrow"-with peanuts up and leaves down. (Bryce Ethridge, 2018)

Recent articles show that there are pros and cons to organic peanut butter with farmers and manufacturers considering the environmental impact of growing the legume in an organic form. It is cheaper to grow organic peanuts vs conventional simply due to the cost of chemicals that would not be utilized. While organic foods contain fewer synthetic chemicals, they aren't always more nutritious, in terms of vitamin and mineral content, than conventionally grown and manufactured foods, according to Jeff Cox (author of "The Organic Food Shopper's Guide."). The peanut does not receive all the right nutrients during the growth stage to produce a well furnish protein peanut. 
Natural peanut butter usually contains just two ingredients, peanuts and salt as well as salt-free varieties for those seeking low sodium alternatives. Conversely, conventional peanut butter includes sugar and hydrogenated vegetable oil to ensure that its consistency is not affected by time or temperature. In order for a product to be labeled as "peanut butter", it must contain at least 90 percent pure peanuts. The additional 10 percent may include salt, sweeteners and hydrogenated vegetable oils. Both natural and conventional peanut butter fit into the category of "peanut butter". (Jeff Cox, author of "The Organic Food Shopper's Guide.").

The demand for organically produced peanuts and cotton represent the fastest growing sector for each of these commodities. Significant price premiums at the producer level are associated with certified organic commodities. However, the incentives that are needed to convert a field or farm from conventional production to an organic production system are not easily or quickly done due to the transition period required for products to be marketed as "Organic". Two years (2004 and 2005) of research on an irrigated and no- irrigated peanut/cotton, transitional organic rotation system was completed at the USDA/ARS National Peanut Research Laboratory's Multi-crop Irrigation Research Farm. Official "Organic Certification" was received in 2006 and research was continued in 2006 in conjunction with on-going irrigated and non-irrigated research in conventionally produced peanut/cotton rotations to provide direct comparisons in terms of production cost(s), yield, grade, and quality. (MC Lamb, 2007)

Florunner peanuts grown in twin $18 \mathrm{~cm}$ rows and conventional $91 \mathrm{~cm}$ rows when subjected to a series of weed control systems ranging from none too intense exhibited a reduction in grasses in the twin row spacing, something that was evident in 2 out of 3 years in the untreated crops according to Wehtje, et. al. (1984). While the twin row spacing affected weeds and yield in a favorable manner, the consistency was insufficient to permit any reduction in herbicide inputs. (Wehtje, R. H. Walker, M. G. Patterson, and J. A. McGuire (1984)

Studies were conducted on crops near Tifton, GA to develop weed management systems for organic peanut production in 2004 and 2005. The trials evaluated row patterns (two levels), remedial weed control (four levels), and cultivation (three levels) results. Row patterns were defined as:"wide rows" (91 cm apart) and "narrow rows" (30 cm apart). Remedial weed control involved early-season applications of clove oil, citric plus acetic acid, broadcast propane flaming, and a non-treated control. Cultivation regimes were $1 \mathrm{X}$ or $2 \mathrm{X}$ sweep cultivation and a non-cultivated control. The experimental sites had heavy natural infestations of annual grasses and broadleaf weeds. (W. Carroll Johnson III and Benjamin G. Mullinix Jr. (2008)

The article, Economics of Weed Control in Peanuts with Herbicides and Cultivations Systemsdocuments that utilizing herbicides alone did not provide highest net returns, peanut yield, or weed control. The effectiveness and profitability of weed control with herbicides and cultivation were determined in peanuts infested with Texas panicum, sickle pod, and pitted morning-glory. Weeds traditionally compete with peanuts for sunlight, moisture, and nutrients and therefore may reduce harvesting efficiency. Weeds are particularly troublesome during the digging and inverting procedures (Young et al., 1982). Weed biomass slows field-drying of peanut vines and pods and increases the likelihood of exposure to rainfall, which may increase harvesting losses (Wilcut et al., 1995; Young et al., 1982)

Effective weed control in peanuts is essential not only from the standpoint of minimizing crop/weed competition, but is also required for effective disease control and harvest efficiency. Herbicides currently available to farmers frequently provide inconsistent weed control which is problematic for peanut farmers and the crops.Fewer options are available for weed control in peanuts than other agronomic crops since the use of post-emergence directed sprays or late-season cultivations are not practical due to the prostrate-growing nature of the peanut plant (Cantowine, et al 2011). Two of the most troublesome weeds documented which compete for nutrients with peanuts grown in the Southeastern United States are Florida beggarweed and sickle pod (Hauser. Buchanan, G.A., D.S. Murray, and E.W. Hauser. 1982).

Florida beggarweed (Desmodium tortuosum) is highly competitive for nutrients and is most destructive to the growth of the peanuts if it emerges within the first eight weeks of planting peanuts Grey, et al 2009). Sickelpod as a weed is destructive due to its ability to germinate at temperatures between $21-36^{\circ} \mathrm{C}$ and being tolerant of wide variances of soil $\mathrm{pH}$ as well as fertility levels. The seeds which are produced in great abundance show viability up to two and a half years after dropping into soil which allows for a perpetual problem in fields that are not "rested" between crops (Lancaster, et. al. 2005).

The southeastern region of the United States has an arid climate and peanut development is generally later in the year than other peanut production areas across the country; hence the time plants are exposed to pathogens is increased. These pathogens cause similar symptoms in the field; therefore, proper diagnosis is needed so that the appropriate management strategies can be implemented. (D. M. Porter, 1997.)Treatment without proper diagnosis does not guarantee successful eradication of the weeds. 
Field experiments were carried out in Georgia and North Carolina to evaluate the efficacy of fungicides approved for the organic management of early leaf spot and late leaf spot, caused in peanut fields planted to cultivars with partial resistance to one or both pathogens. Copper treatments alone or in mixtures resulted in less disease than a non-treated control. In Georgia, sulfur provided some disease suppression, but not as much as treatments with copper sulfate. Neem oil did not affect disease severity. Mean pod yields across years were significantly greater than the non-treated control only for copper sulfate in Georgia and cupric hydroxide in North Carolina. The minimal yield response to treatments suggests that under similar situations, the frequency of copper-based fungicide applications may be reduced with little effect on yield. (Cantonwine, E. G., Culbreath, A. K., Shew, B. B., and Boudreau, M. A. 2008)

Fungal diseases is remains a major factor limiting profit in the production of Virginia-type peanuts in the South Carolina coastal plain area. Field tests were conducted over a three-year period (2006-08) evaluating the disease resistance of 47 experimental Virginia-type breeding lines and eight cultivars. Relative to commercially available standards, cultivar Bailey (recently released by N. C. State Univ.), three sister lines:N03088T, N03089T, and N03090T; N03091T were found to have consistently less susceptibility to tomato spotted wilt virus; late leaf spot and stem rot. The level of field resistance measured for these three diseases was comparable to that of a resistant runner-type cultivar, Georgia-03L. (Barry L. Tillman (2010)

Maximum and minimum peanut input production tests were conducted for three consecutive years (2004-06) to evaluate agronomic performance and economic return among several runner and Virginia genotypes. Mid-April planting dates were used each year. The Max tests included recommended production practices of seeding rate, fertilization, irrigation, and pesticides; whereas, the Min tests excluded irrigation, insecticides, and included only three fungicide sprays. Results showed variation among years, locations, and genotypes for TSWV and total disease incidence, pod yield, gross dollar value, and dollar value return above variable cost. The performance results also show the benefit to growers from agronomic and economic improvement with many of the newly released peanut cultivars in Georgia. (W. D. Branch and S. M. Fletcher (2010).

Stand establishment has been a challenge for organic peanut production in the Southeastern United States. Field experiments were conducted in 2007 and 2009 in research plots certified for organic production to evaluate the potential of genotype selection, shelling procedure, and seed treatment with Bacillus subtilis to improve stand establishment and seedling emergence rates, reduce incidence of Aspergillus crown rot, and increase seedling biomass. Seed of 15 peanut genotypes were mechanically shelled or hand-shelled, and treated with B. subtilis or untreated prior to planting in early June(M.A. Boudreau (2011). It has also been shown that treatment with copper sulfate of seeds before planting providing roughly $18 \%$ stand efficiency as observed at four weeks post-planting. This is encouraging and is indicative of further need for research on the effects of copper on peanut seed germination, this is important as copper sulfate is considered an "organic" treatment and would not compromise the listing of a farm as "organic" in nature

\section{Methodology}

\section{Population/Site Selection}

This study will be done in Albany Georgia on land being leased to own by the student researcher. The location is 1803 Cordele Road, Albany, Georgia and consists of a ten acre plot where five acres are planted in organic peanuts using three different varieties. The varieties are runner types known as Georgia 12Y, Georgia 06-G, and Florrun331. The soil type is a clay type soil with a pH of 5.6 based on a soil analysis test taken on March 13th 2018. The land has been certified "organic" as of July 25, 2018 by Georgia Crop Improvement Association. The land on which the project will be conducted is certified organic by Georgia Crop Improvement Association located in Athens, Georgia. The seeds used for this project are non-treated seeds from the runner variety that is commonly grown in Georgia to include Ga 12Y, Ga 06G, and Florrun 331. These are the three varieties of peanuts that are currently planted on the plot. Each variety is planted in one acre plots, with each plot having 15 rows that are 900 feet long. There is a total of 43,560 square feet in one acre of land.

\section{Sample Propagation and Collection:}

The research will take place utilizing a 2018 peanut crop located at 1803 Cordele Road, Albany, GA. Seeds were planted in rows approximately one foot apart with 36 inches spacing between each rows and 2 inches in depth in clay type soil. The growing season observed is from early April to mid- May and crops will be harvested within 140 days of May 15th. The peanuts which were planted May 16, 2018 have an expected harvest date of October 5, 2018. 
The samples to be collected will include independent, randomly selected samples of each variety which are stored in separate trailers during harvesting to avoid cross contamination. Peanuts will then be transported to the peanut mill located in Cordele Georgia, known as GFA Peanut Company before being transported to a Sheller company that is organic certified this year by the name of GFA Sheller's. This organization primarily operates in the Peanut Shelling business/industry within the Agricultural Services sector and has been in business for approximately 29 years. At GFA Peanut Co., the peanuts will be cleaned, dried, and weighed to see the comparison of average weight per acre to that of conventional "non-organic" peanuts. The peanuts then will be graded based on size and weight before storing into a final trailer. Once the peanuts are loaded on the trailer, the peanut mill runs the peanuts through a machine that cleans them before returning them back to a trailer for drying before they are either sold, shelled, or usedas seeds for future crops. Peanuts are regarded as a "closed" commodity, meaning that once the peanuts have been through the process, the student researcher will not be able to get any peanuts back from the company. For this reason, all analysis and data collection will have to take place at the peanut mill in Cordele Georgia.

Student research will take five pounds of each variety and assess the size, moisture percent and the grade of the peanuts. Once the trailer of peanuts has been taken to the processor, they are no longer available for analysis. The peanut mill will process the peanuts through a machine that will be able to determine the moisture content of each variety. This procedure will provide the results on the same day that peanuts were turned in to the mill. Looking at the size of the peanut is something that will be done with a naked eye and is somewhat of a subjective measurement. The peanut size will help determine if the peanuts received the right amount of nutrients during the growing process. A small peanut means that not enough nitrogen taken in from the soil so therefore it will be not enough fertilizer. A peanut that is average size means that there were enough nutrients available for the nut to produce.

Grading peanuts is also simple as well with a machine that runs the peanuts through another machine that will separate them based on grade which is fullness of space inside the peanuts. A better understanding of how it works is if one were to take the peanut and crack it open, it is possible to see the size of the nut in the shell and how full the shell is. A peanut seed that is tight to the shell and does not rattle when shook is a grade A type peanut. If the shell rattles, the nut inside is small and isn't a grade A type peanut.

Checking the moisture content involves looking at the seed to assess how much moisture is still inside the peanut to determine how long it will take for peanuts to dry before they are shelled, etc. The moisture content is very important because if there is too much moisture in the peanuts, they are prone to mold contamination. The moisture percentage should be a dryness of $11 \%$ before they are able to be safely stored. Many peanut mills do nut shell peanuts until the following year just to let them dry out inside the shell.

\section{Statistical Program and Analysis}

There was no need for statistical analysis; however the yield was at the minimum required pounds per acre for all there varieties.

\section{Field Photos}
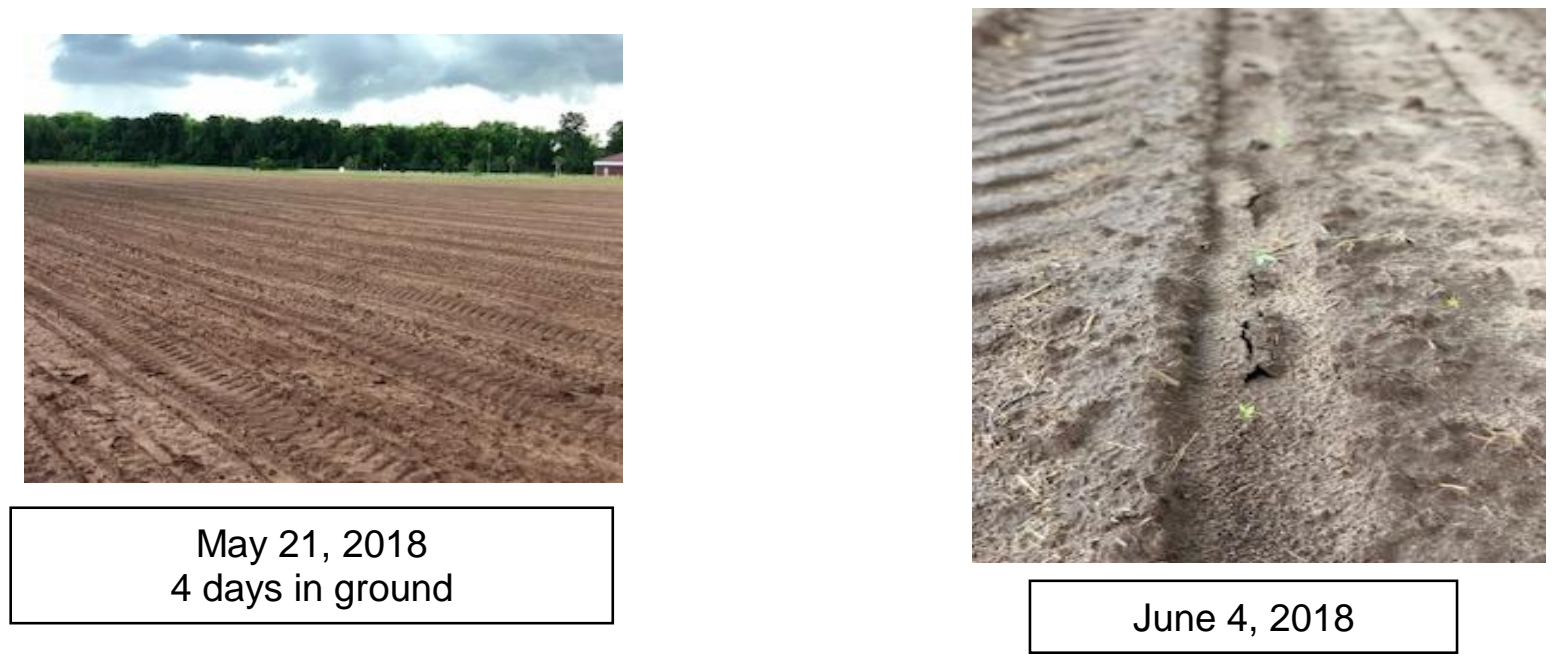

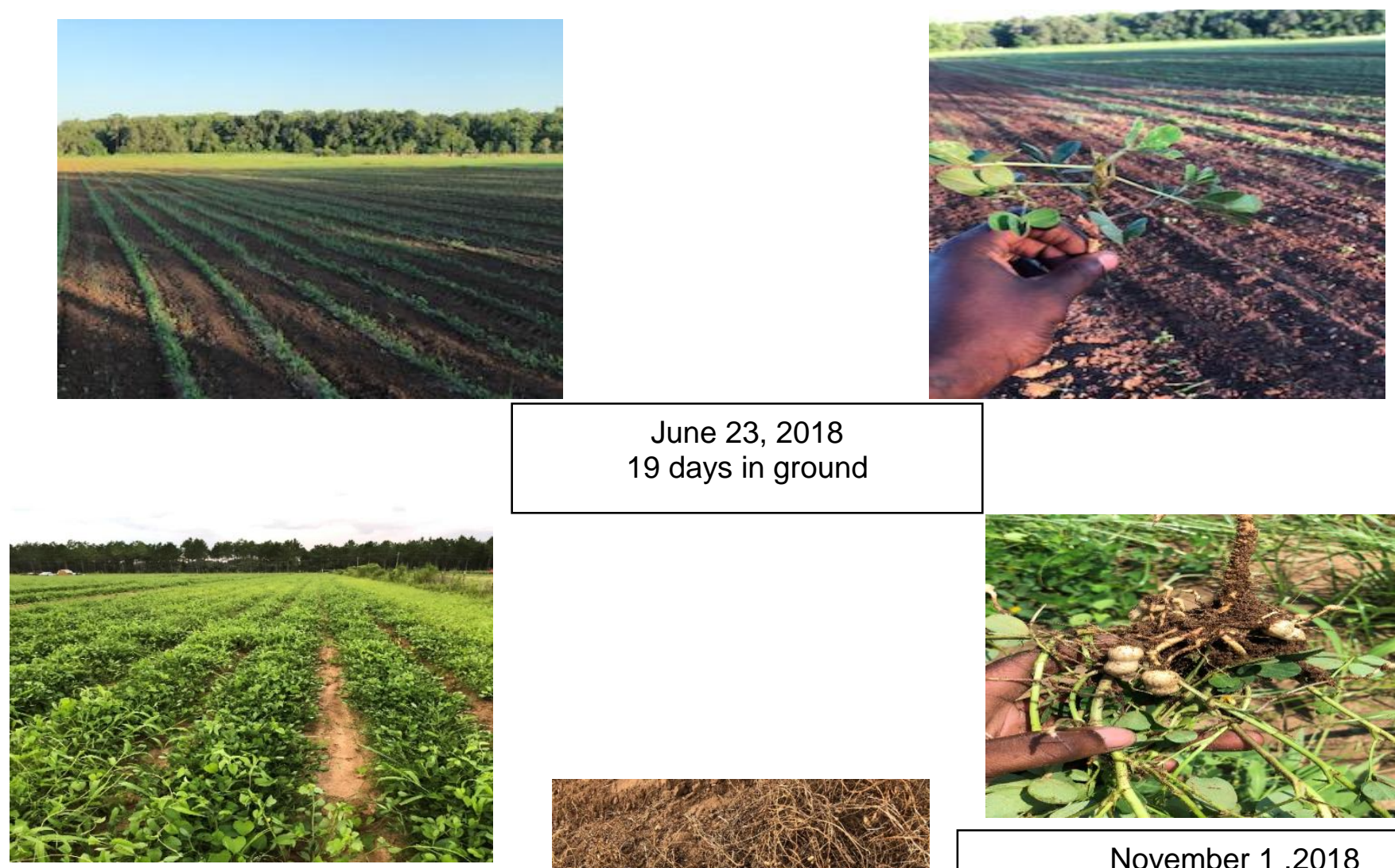

July 262018

70 days in ground
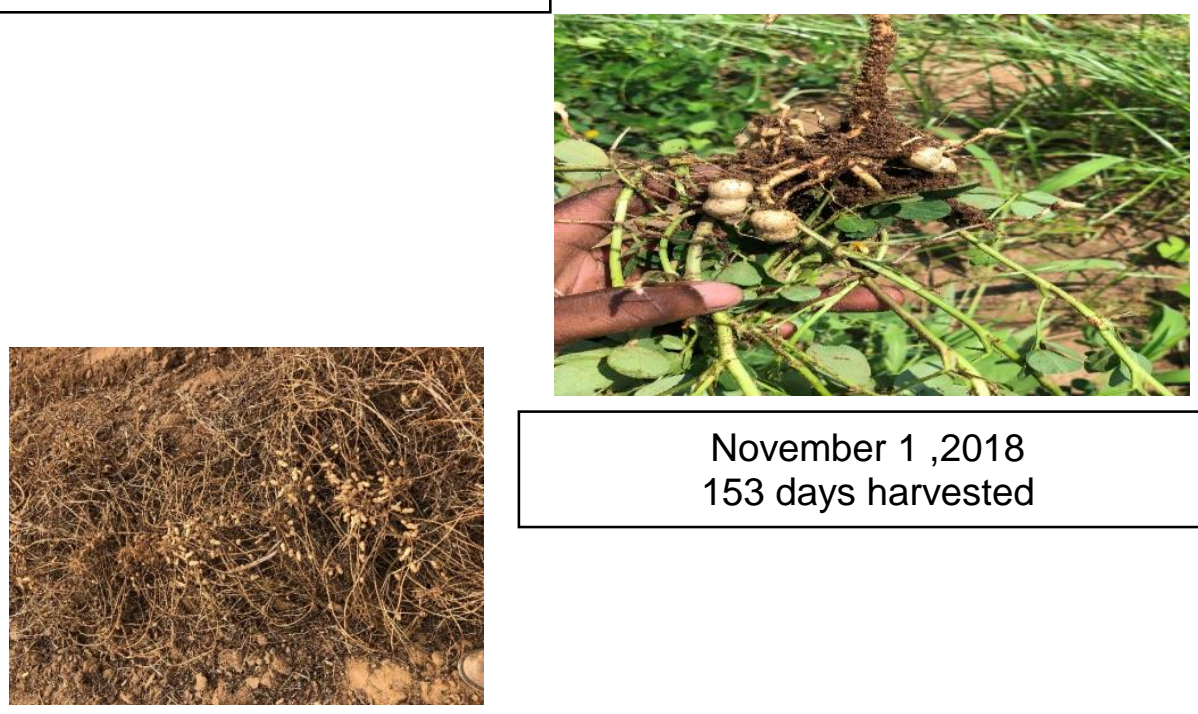

November 1,2018 153 days harvested

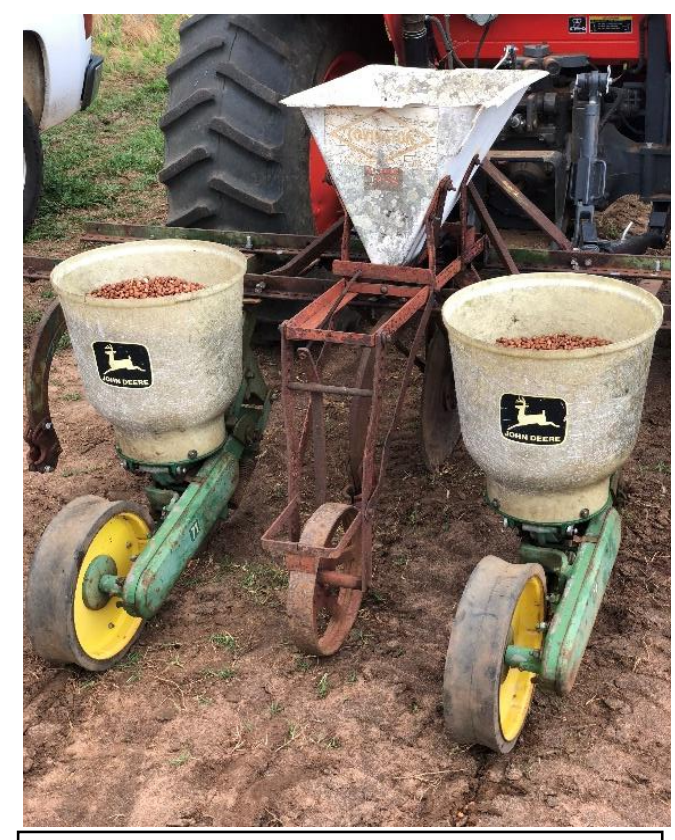

1971 John Deere 2 row planter

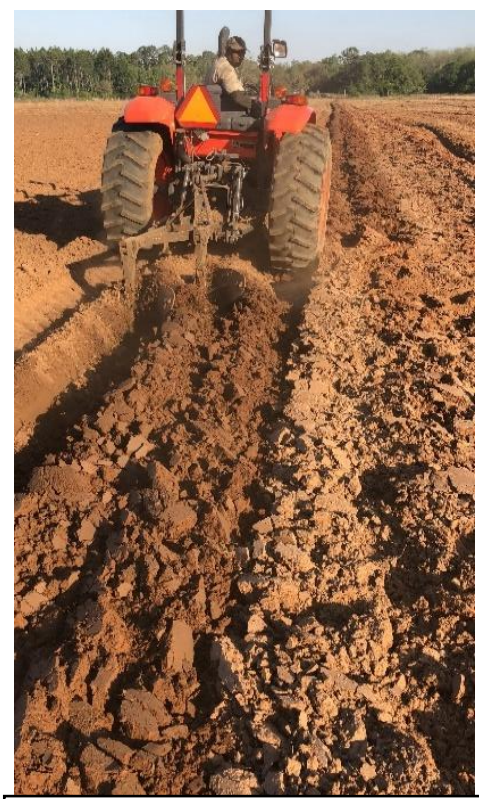

Flipping over the soil April 15, 2018

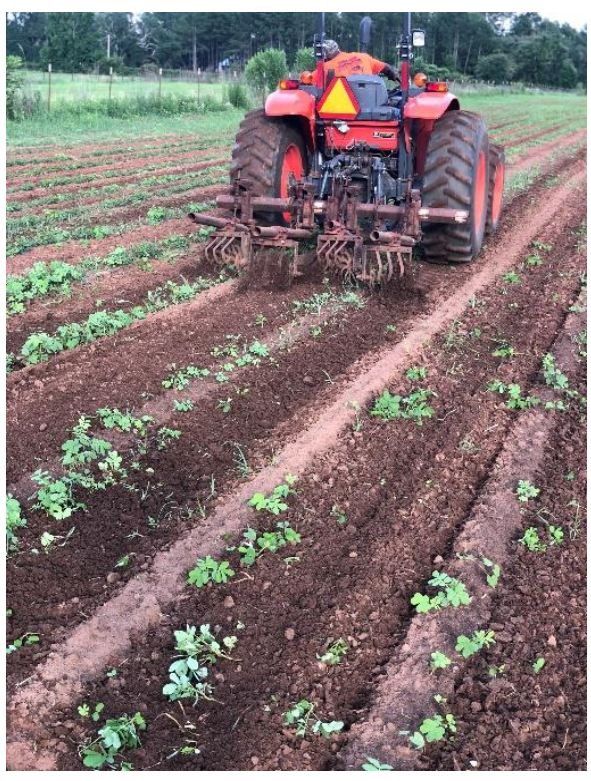

Two row rolling cultivator used for weed control. 

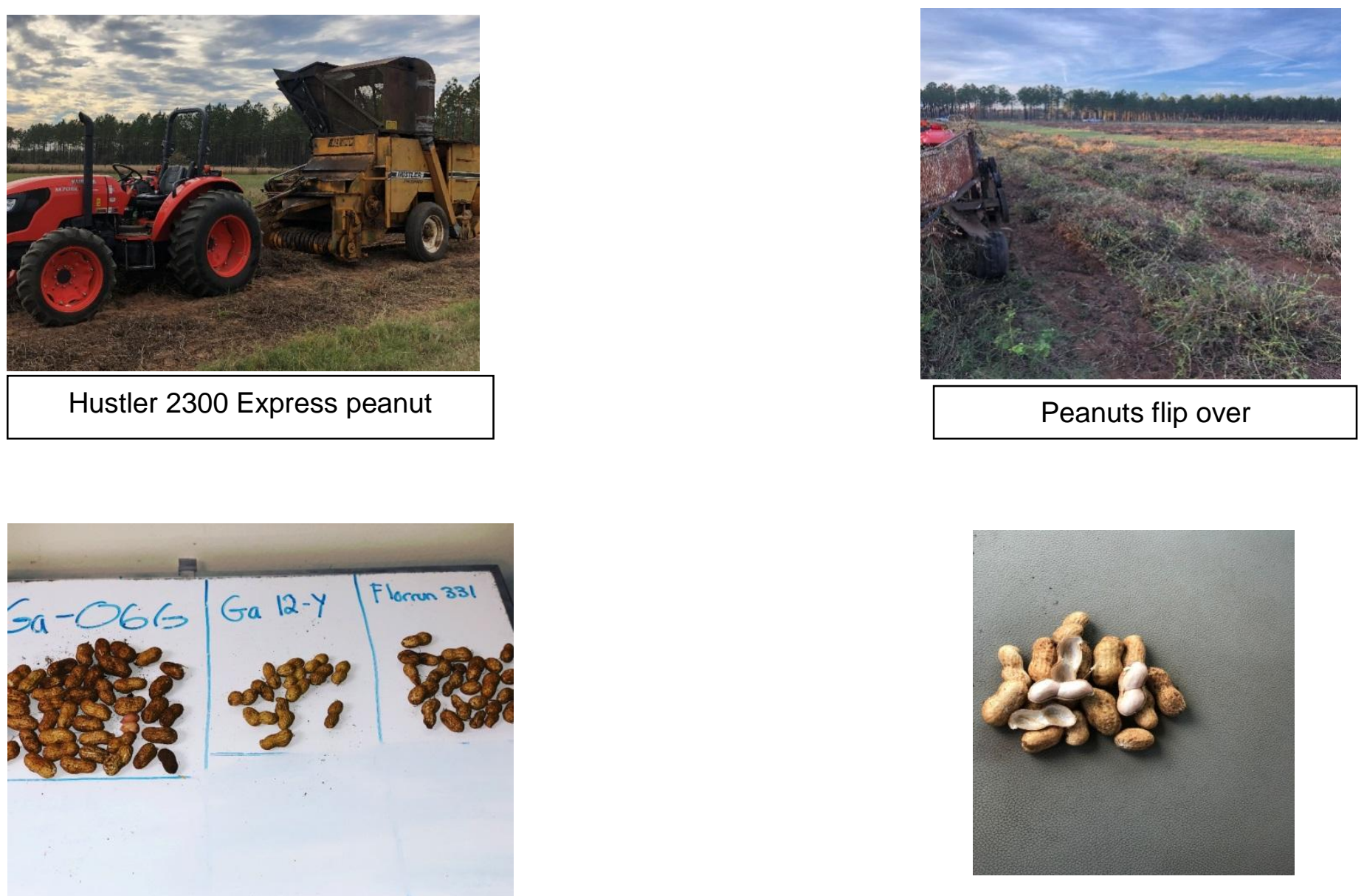

\section{Peanuts Displayed Shelled (L) and Non-Shelled}

\section{Results}

After the harvest of the peanuts there was a count of 1,300 pounds to the acre which provided a gross net of about 5,000 pounds. This is a good yield for the first year of growing organic peanuts. Upon grading, the yield was that $60 \%$ of the peanuts were jumbo size which is slightly under the $70 \%$ margin that is recognized by the industry as a "good" crop. Because of the "organic" status, the peanuts were sent off to a diagnostic lab to be tested for presence of herbicide, insecticide, or pesticide usage; all items that would negate the "organic" status. Conventional peanuts, when tested will show that an herbicide was used to control weeds in the field which such as Flumioxazin and dimethylamine salt.

The expected results of organic peanuts that were not exposed to chemicals will have a zero percent or ratio of chemical contamination. Other chemicals may be found in conventional peanuts; however, it is often difficult to determine the exact type of chemical used as farmers often try new chemicals each year and spray for different results. The results showed that the organic peanuts do not have any type of chemical residue within the shower or on the peanut itself. (NPK) Nitrogen (N), phosphate (P2O5), and potash (K2O) were the most widely used fertilizer materials used on conventional and organic peanuts, however these forms of nutrients come in organic form and therefore are safe to fertilize the organic peanuts with. Fertilizer was applied to include: nitrogen on $40 \%$ of planted peanut acres at an average rate of 31 pounds per acre. Phosphate and potash was applied to $42 \%$ of acreage at an average rate of 43 and 72 pounds per acre. (Refer to chart for data results).

\section{Discussion}

Peanut allergy is one of the most common causes of severe allergy attacks and can be life-threatening, causing anaphylaxis shock in severe cases. For some people with peanut allergy, even tiny amounts of peanuts can cause a serious reaction. Peanut allergy occurs when the immune system mistakenly identifies peanut proteins as something harmful. 
Direct or indirect contact with peanuts causes the immune system to release symptom-causing chemicals into your bloodstream. Immunoglobulin $\mathrm{E}$ ( $\mathrm{IgE}$ ) is a type of protein found in our immune system that identifies foreign objects, such as bacteria. This protein is also involved in anaphylaxis shock which can occur in some who are allergic to peanuts. Five percent of children allergic to peanuts may react to other legumes. Many years ago, it was common to recommend avoidance of legumes, including soy, because of a peanut allergy; but this practice has been proven necessary. By growing organic peanuts without chemicals which may incite the plant to make more reaction-causing protein, it may be possible to offer a product that can be consumed by all populations without fear of reaction.

\section{Summary:}

Although peanut is a legume, most peanut-allergic individuals will also tolerate other legumes, such as soy, peas, and green beans. The student researcher was successfully in growing certified and tested organic peanut crop that produced a good yield. The peanuts also had acceptable moisture content and size as well as less of a protein burden that could contribute to allergic reactions. Therefore, in answer to the question of how do we reduce the allergic reaction that people are having in peanuts? We grow a healthy organic peanut that has less protein and therefore may be ingested without triggering immune responses of the human body while providing the nutrition for which peanuts are known.

\section{Conclusion/Recommendations:}

Studies show that the highly refined oils of organic peanuts can be safely eaten by those with food allergies to peanuts. Highly refined oils from organic peanuts contain extremely small levels of allergenic protein. More than half of peanutallergic individuals will have a positive skin test or blood allergy test to another legume. People with a peanut allergy must avoid peanut in all forms including candies and items that are fried in peanut oil. Children with a peanut allergy also must avoid anything containing traces of peanut ingredients in it as their small size may induce more severe reactions to fewer products.

To avoid the risk of anaphylactic shock, people with a peanut allergy must be very careful about what they eat. Peanuts and peanut products are commonly found in candies, cereals and baked goods, such as cookies, cakes and pies. If eating out, it is advisable to ask the restaurant staff about ingredients as well as oils that are used for cooking.This is especially important in eating Asian and Mexican food and other n-American cuisines in which peanuts are commonly used. Ice cream parlors are a common area of concern that many do not recognized that may be dangerous for those with peanut allergies as peanuts are a common topping.

\section{Appendices}

\section{APPENDIX A: TABLE: Grading Report for 2018 Crop}

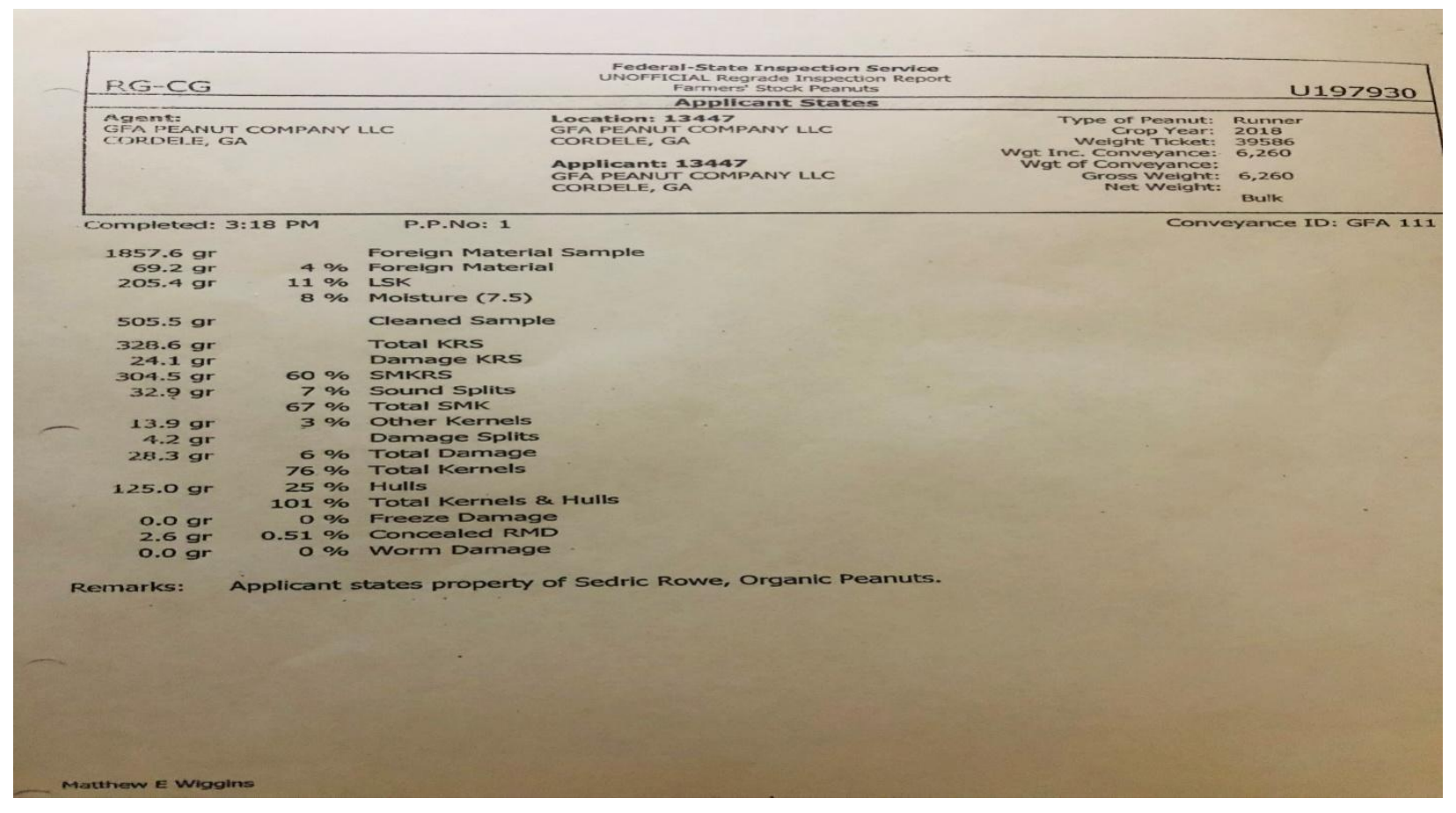




\section{References}

Buchanan, G.A., D.S. Murray, and E.W. Hauser. 1982. Weeds and their control in peanuts. pp. 206-249. H.E. Pattee and C.T. Young (eds.). Peanut Science and Technology. Amer. Peanut Res. Educ. Soc., Yoakum, TX 77995.

D. Q. Wann and R. S. Tubbs. (2014) Interactive Effects of Hand Weeding, Tine and Sweep Cultivation for Weed Control in Organic Peanut Production. Peanut Science 41:2, 124-130. Online publication date: 12-Aug-2014.

D.Q. Wann, R.S. Tubbs, W.C. Johnson III, A.R. Smith, N.B. Smith, A.K. Culbreath and J.W. Davis. (2011) Tine Cultivation Effects on Weed Control, Productivity, and Economics of Peanut under Organic Management. Peanut Science 38:2, 101-110. Online publication date: 21-Dec-2011.

E.G. Cantonwine, C.C. Holbrook, A.K. Culbreath, R.S. Tubbs, and M.A. Boudreau (2011) Genetic and Seed Treatment Effects in Organic Peanut. Peanut Science: July 2011, Vol. 38, No. 2, pp. 115-121.

E.G. Cantonwine, C.C. Holbrook, A.K. Culbreath, R.S. Tubbs and M.A. Boudreau. (2011) Genetic and Seed Treatment Effects in Organic Peanut. Peanut Science 38:2, 115-121.

Ganapathy, T., and Narayanasamy, P. 1990. Effect of plant products on the incidence of major diseases of groundnut. Int. Arachis News. 7:20-21.

Grey, TL, Prostko, EP, Wehje, GR (2009) Florida beggarweed (Desmodium tortuosum) management in peanut (Arachis hypogaea) with residual herbicides. Retrieved from: www.peanutscience.com on 5-2-2019.

Hammons, R.O. 1973. Early history and origin of the peanut. pp. 17-45. Peanuts - Culture and Uses. Amer. Peanut Res. Educ. Assoc., Stillwater, OK 74074.

Jay W. Chapin, James S. Thomas, Thomas G. Isleib, Frederick M. Shokes, William D. Branch, and Barry L. Tillman (2010) Field Evaluation of Virginia-Type Peanut Cultivars for Resistance to Tomato Spotted Wilt Virus, Late Leaf Spot, and Stem Rot. Peanut Science: January 2010, Vol. 37, No. 1, pp. 63-69.

Kemerait, R. C., Brenneman, T. B., and Culbreath, A. K. 2005. Peanut disease control. Pages 122-125 in: 2005 Georgia Pest Management Handbook, Commercial Edn. P. Guillebeau, ed. Coop. Ext. Ser., Univ. of Georgia, Athens.

Lancaster, SH, Jordan, DL, Spears, JF, York, AC, Wilcut, JW, Monks, DW, Batts, RB, Brandenburg, RL (2005). Sicklepod (Senna obtusifolia) Control an Seed Production after 2-4DB Applied Alone and With Fungicides or Insecticides. Weed Technology, Volume 19: 4541-455.

MC Lamb, JR Sholar, I Nickels - Proceedings of the 38th Annual Meeting of the ..., 2007 Peanut Res. Lab., Dawson, GA 39842. 2University of Georgia, Coastal Plain Expt. Stn., Tifton, GA 31793.

Potential Weed Management Systems for Organic Peanut Production W. Carroll Johnson, III* and Benjamin G. Mullinix, Jr.1

W. Carroll Johnson III, Albert K. Culbreath and Xuelin Luo. (2018) Interactive Effects of Cultivation, Insect Control, and Fungal Disease Control in Organic Peanut Production. Peanut Science 45:1, 38-44. Online publication date: 5-Jul-2018.

W. D. Branch and S. M. Fletcher (2010) Agronomic Performance and Economic Return among Peanut Genotypes with Maximum and Minimum Production Inputs. Peanut Science: January 2010, Vol. 37, No. 1, pp. 83-91.

Wehtje, G., R.H. Walker, M.G. Patterson, and J.A. McGuire. 1984. Influence of twin rows on yield and weed control in peanuts. Peanut Sci. 11:88-91.

Wilcut, J.W., G.R. Wehtje, and R.H. Walker. 1987. Economics of weed control in peanuts (Arachis hypogaea) with herbicides and cultivations. Weed Sci. 35:711-715. 